\title{
ЦИФРОВИЗАЦИЯ КАК ДРАЙВЕР РАЗВИТИЯ ЭКОСИСТЕМЫ УЧЕБНОГО ЦЕНТРА
}

\author{
Домнышев Алексей Владимирович \\ аспирант \\ Научный руководитель: Затепякин Олег Аркадьевич \\ Д.э.н. доцент \\ ФГБОУ ВО «Сибирский государственный \\ индустриальный университет»
}

\begin{abstract}
Аннотация: B работе представлены основные направления цифровизации учебного центра как обучающей экосистемы. Цифровизация реализуется в настоящее время по нескольким ключевым направлениям, позволяющим оперативно реагировать на задачи бизнеса, совершенствуя процессы, инструменты развития и обучающие системы, и является одним из ключевых драйверов развития учебного центра.

Ключевые слова: Цифровизация, автоматизация процессов, самоходная техника, обучающая система, снижение затрат, эффективность производства.
\end{abstract}

\section{DIGITALIZATION AS A DRIVER FOR THE ECO SYSTEM DEVELOPMENT OF THE TRAINING CENTER}

\author{
Domnyshev Aleksey Vladimirovich \\ Aspirant \\ Academic Supervisor: Zatepyakin Oleg Arkadevich \\ Doctor of Economics Associate Professor \\ The Siberian State Industrial University
}

\begin{abstract}
The paper presents the main directions of digitalization of the training center as a training ecosystem. Digitalization is currently being implemented in several key areas that allow you to quickly respond to business tasks, improving processes, development tools and training systems and is one of the key drivers for the development of the training center.
\end{abstract}


Key words: digitalization, process automation, self-propelled equipment, training system, cost reduction, production efficiency.

\section{Введение}

Эпоха технологических открытий представляет угрозу для отраслей, компаний и человечества, но вместе с тем становиться огромной возможностью. [1] В настоящее время большая часть компаний одними из ключевых направлений развития выделяет автоматизацию, цифровизацию производства. Это позволяет компаниям:

- внедрять современные технологии, обладающие меньшей себестоимостью,

- более оптимально расходовать ресурсы, за счет использования цифровых подсказчиков;

- существенно снизить численность персонала и др.

В свою очередь, современные производства требует совершенно другого уровня развития компетенций у персонала, повышения их внутренней конкурентоспособности: мультискиллинг и владение цифровыми технологиями [2]. Обучающая экосистема предприятия, направленная на обеспечение потребности организации персоналом, как в текущем моменте, так и на перспективу, должна на опережение внедрять данные технологии в обучении, для соответствия запросам бизнеса.

На примере экосистемы регионального центра подготовки персонала «Евраз-Сибирь» рассмотрим основные направления связанные с внедрением в образовательный процесс курсов по автоматизации, цифровизацию подходов в обучении.

Основные направления цифровизации экосистемы

За последние три года, основные трансформации процессов обучения происходили по следующим направлениям:

1 Расширения перечня образовательных программ, связанных с использованием микропроцессорной техники, различных видов приводов и контролеров.

2 Внедрение современных инструментов он-лайн обучения, а также с использованием дистанционных технологий.

3 Разработка и использование современных тренажеров-симуляторов, связанных с внедрением на производстве технически сложной самоходной техники. 
4 Цифровизация системы администрирования процессов обучения.

Более подробно рассмотрим каждое направление изменение экосистемы.

1 Расширения перечня образовательных программ, связанных с использованием микропроцессорной техники, различных видов приводов и контролеров. Значительные изменения производства, запуск современных автоматизированных комплексов повлек необходимость значительного развития материально-технической базы и внедрение целого перечня дополнительных практикоориентированных образовательных программ.

В рамках развития лабораторной базы были закуплены: современные мехатронные комплексы фирмы «Фесто-Дидактик, контролеры «Овен», «Logo»,...Общие инвестиции за 2019-2020 год составили более 15 млн. руб. Уникальность курсов в том, что позволяют:

- моделировать управление производственными процессами,

- отрабатывать различные алгоритмы,

- осуществлять поиск и устранение неисправностей и т.д.

Данные действия невозможно выполнить на действующем оборудовании, а в случае его остановки необходимо быстро определить и устранить неисправности, так как один час простоя основных агрегатов влечет потери нескольких миллионов маржинального дохода. Так, например, курс «Мехатроника» включает в себя отработку алгоритмов действий при возникновении неисправностей сразу нескольких специалистов различных служб. В ряде производств за последние два года уровень простоев оборудования был снижен на $30 \%$, в том числе и за счет своевременных, квалифицированных действий персонала.

2 Внедрение современных инструментов он-лайн обучения, а также с использованием дистанционных технологий. В данном направлении необходимо выделить два основных направления:

- перевод всех направлений подготовки руководителей и специалистов по обязательному обучению в области охраны труда, промышленной безопасности и др. в формат видеоконференций на платформе ZOOM. В среднем в месяц этим охвачено около 600-700 человек. Это позволило более гибко организовывать процесс: сотрудник может проходить обучение как с рабочего места, так и с домашнего компьютера; снизить временные потери, связанные с 
перемещением в учебный центр; расшить ограничения, связанные с пропускной способностью учебных помещений;

- увеличение курсов дистанционного обучения в системе Web Tyter. Это позволило более гибко во времени организовать образовательный процесс по времени для сотрудников, постоянно совершенствовать материалы курса, сохранить коммуникации между обучающимся и экспертом. Суммарный охват около 150 сотрудников в месяц.

3 Разработка и использование современных тренажеров-симуляторов, связанных с использованием технически сложной самоходной техники. Внедрение современного оборудования, замещение ручного труда машинным потребовало внедрения новых подходов в подготовке персонала. Одним из ключевых мероприятий в 2018-2020 годах стало внедрение самоходной техники на горнодобывающих предприятиях компании, таких как погрузочнодоставочные машины (ПДП), проходческие буровые машины, машины очистного бурения и др. Внедрение техники потребовало кардинального изменения схемы обучения, после прохождения теоретического курса работниками д.б. готовыми к управлению техникой, имея базовые навыки по ее эксплуатации. Решением этой задачи стало разработка и запуска совместно с УЧТЕХ-ПРОФИ тренажеров-симуляторов самоходной техники. Тренажеры полностью моделируют управление техникой и позволяют:

- освоить органы управления техникой;

- проводить управление техникой в режиме тренировке;

- проводить управление техникой в режиме сдачи экзамена;

- отрабатывать нештатные ситуации и др.

За 2020 год на тренажерной технике прошли подготовку более 60 сотрудников, а в 2021 году кроме подготовки дополнительно были организованы конкурсы профессионального мастерства сотрудников предприятий. Результатом стало значительное повышение качества подготовки, сокращение сроков адаптации сотрудников к технике, снижение инцидентов и аварий в период практического обучения на действующем оборудовании.

Инвестиции на разработку тренажеров симуляторов составили более 13 млн. руб. В 2021 году принято решение продолжить успешную практику и продолжить разработку симуляторов по дополнительным направлениям, связанным с безопасностью труда и управлением технологическим процессом с применением виртуальной реальности. 
4 Цифровизация системы администрирования процессов обучения.

Расширение направлений обучения, необходимости оперативного администрирования от определения потребности и регистрации на курсы до завершающих мероприятий и выдачи соответствующих документов требовало большого количества человеческих ресурсов, что тем не менее не гарантировало своевременного и качественного выполнения задач. Решением этих задач стало разработка и внедрение системы управления обучением (LMS), позволившая интегрировать все процессы и пользователей. LMS позволила интегрировать:

- графики обучения;

- предварительную он-лайн регистрацию на курсы;

- формирование учебно-учетной документации: приказы, протоколы, свидетельства, удостоверения,

- электронные табеля;

- формирование данных по обученности.

При этом внедрение системы позволило более чем на 50\% сократить трудозатраты и повысить производительность, перераспределив ресурсы на другие задачи. Кроме того, интеграция LMS с информационными системами заказчика существенно снизила трудозатраты на его стороне.

\section{Заключение}

Таким образом, в рамках развития учебно-материальной базы и трансформации подходов в подготовке, их цифровизации были реализованы несколько ключевых направлений, связанных как с организацией обучения, трансформации подходов обучения, так и самими инструментами развития сотрудников под изменяющуюся технологию и оборудование на производстве. Более 30 млн. руб. были инвестированы на развитие экосистемы за два года в данное направление, это стало одним из ключевых драйверов развития экосистемы, при этом положительно отразилось на простоях оборудования, снижении времени на устранение нештатных ситуаций.

\section{Список литературы}

1. Сибел Томас. Цифровая трансформация. Как выжить и преуспеть в новую эпоху / Томас Сибел // М.: Манн, Иванов и Фербер, 2021 - 256 с.

2. Вайл, П. Цифровая трансформация бизнеса: Изменение бизнес-модели для организации нового поколения / П.Вайл // Москва : Альпина Паблишер, 2019. - $257 \mathrm{c}$. 